Vol. 5, No. 1, 2020

\title{
QUALITY ASSESSMENT AND A LEVEL OF TECHNOGENIC LOAD ON THE SURFACE WATERS OF THE KHERSON REGION
}

\author{
Angelina Chugai \\ Odessa State Environmental University, \\ Department of Environmental Science and Environmental Protection, \\ 15, Lvivska Str., Odessa, 65016, Ukraine \\ avchugai@ukr.net
}

https://doi.org/10.23939/ep2020.01.044

Received: 09.02.2020

(C) Chugai A., 2020

\begin{abstract}
The paper deals with the assessment of a surface water quality in the Kherson region, as well as the assessment of a technogenic load on the surface water bodies by the volumes of the wastewater and pollutants discharges over a long period of time. The problem of supplying the regions of Ukraine with water is urgent for many regions, including the Kherson region. The materials from the Regional reports, Ecological passports on monitoring a state the surface water as well as the data on the volumes of the sewage and pollutants discharges were used as baseline data. Water quality indicators was analyzed using the graphical method of a surface water quality complex assessment and method of estimation of surface water quality, based on hydrochemical parameters. Authors proposed to estimate a level of technogenic load on the surface water based on the calculation of the technogenic load module on the water objects $\left(M_{W O}\right)$. The purpose of the work was to assess a quality of the surface waters of the Kherson region as well as to assess a level of technogenic load on the surface water bodies of the region. It is obtained that a surface water quality of the region according to the fishery requirements in the most cases is characterized by classes IVa-IVd, category "very dirty", by drinking water - class II, category "polluted", class IIIa, category "dirty". There were significant exceedances of $M P C$ according to fishery standards in terms of such substances as nitrites, $\mathrm{Cr}$ (VI), $\mathrm{Cu}$ and $\mathrm{Ni}$. Maximum excesses were noted for $\mathrm{Cr}$ (VI) content. Also significant exceedances of the fisheries standards were observed in the content of sulfates, phosphates, $\mathrm{Mn}, \mathrm{BOC} \mathrm{C}_{5}$, mineralization and others. In terms of economic and drinking requirements, the $M P C$ was most often observed in such indicators as
\end{abstract}

mineralization, $B O C_{5}$ and $\mathrm{Ni}$.With a general increase in water intake there is a decrease in the pollutants discharges. A level of technogenic load on the surface water bodies has significantly decreased. The obtained results are a part of a comprehensive study, which are devoted to the complex assessment of technogenic load on the surface water bodies of the Northwest Black Sea regions.

Key words: surface water, discharge, quality, technogenic load module.

\section{Introduction}

The problem of supplying the regions of Ukraine with water is urgent for many regions, including the Kherson region. An important aspect is providing the population with high-quality drinking water as well as adhering to the water quality requirements for fishery.

There are 24 small rivers with floodplains, 693 lakes, one reservoir (Kakhovske), 22 estuaries, the waters of the Black and the Azov seas in the Kherson region. The largest water users of the region are agriculture and public utilities, as well as industrial enterprises as a whole. The most intensive use of water resources in the region is in the steppe zone. Wastewater discharge is carried out into the Kalanchak River, the Kalanchak estuary and the Black Sea [1].

In 2017, according to the data [1], 1218 water users were registered. Seven enterprises are the main pollutants of the water bodies. 


\section{Theoretical part}

The materials from the Regional reports, ecological passports on monitoring the state of the surface water, as well as the data on the volumes of the sewage and pollutant discharge, were used as baseline data.

The dynamics of changes in the water quality indicators was analyzed using the graphical method of complex assessment of the surface water quality. This method is based on drawing up a graphical model of the surface water quality, which is a pie chart with the radius scales corresponding to a certain hydro-chemical indicator. The division value of each radius is equal to the maximum value of the concentration of the indicator, which determines the suitability of water for a certain type of water use, i.e. MPC of the pollutant in the water body [2].

The technique for assessing the quality of the surface water by the hydrochemical parameters was applied (Hydrochemical Institute methodology) for a more detailed assessment of a surface water quality within the Kherson region and for determining the water quality classes [3]. According to this technique, the quality of water is determined by a complex indicator, called the Combinatorial Pollution Index $(C P I)$ :

$$
C P I=\sum_{i=1}^{n} S_{i},
$$

where $S_{i}$ is the total assessment score obtained by multiplying the rate of reocurrence of MPC excess and the MPE excess ratio.

In the work [4] the authors proposed to estimate a level of technogenic load on the surface water based on the calculation of the technogenic load module on the water objects $\left(M_{W O}\right)$, which is defined as a volume of wastewater discharges (pollutants) into the surface water bodies in thousand tons $/ \mathrm{km}^{2}$ per year.

\section{The aim of the study}

The purpose of the work was to assess a quality of the surface waters of the Kherson region as well as to assess a level of technogenic load on the surface water bodies of the region.

\section{Results and Discussion}

According to the available data, the information on the list of the water quality indicators during the study period is very diverse. The surveys of a level of the surface water pollution in the Kherson region were carried out by several organizations (the State Environmental Inspectorate in the Kherson region, the
Basin Department of the Water Resources of the Lower Dnieper and the Kherson Regional Center for Hydrometeorology). From 10 to 17 quality indicators were analyzed in different years: dissolved oxygen, sulfates, chlorides, mineralization, $B O C_{5}$, ammonium nitrogen, nitrites, nitrates, phosphates, total $\mathrm{Fe}, \mathrm{Cr}$ (VI), $\mathrm{Mn}, \mathrm{Cu}, \mathrm{Ni}, \mathrm{Zn}, \mathrm{Mg}$, phenols, oil. The assessment was carried out for two types of water using: fisheries and economic-drinking. Fig. 1 shows the results of estimating the dynamics of indicators changing using the graphical method for individual years (the analysis was carried out for 2005-2018).

The analysis of the obtained data shows that in 2005 there were significant exceedances of $M P C$ according to fishery standards (>10 MPC) in terms of such substances as nitrites, $\mathrm{Cr}$ (VI), $\mathrm{Cu}$ and $\mathrm{Ni}$. Maximum excesses were noted for $\mathrm{Cr}$ (VI) content. In 2009 the $C u$ content decreased (to 5-6 MPC). Also significant exceedances of the fisheries standards were observed in the content of sulfates, phosphates, $M n, B O C_{5}$, mineralization and others. In terms of economic and drinking requirements, the $M P C$ was most often observed in such indicators as mineralization, $\mathrm{BOC}_{5}$ and $\mathrm{Ni}$.

The Kherson region is an agricultural region. Therefore a high content of nitrogen and phosphorus compounds is a consequence of agricultural production. The Ingulets River also flows through the region, its chemical composition is formed under the influence of highly mineralized sewage of the Krivoy Rog iron ore basin. It should be noted that heavy metals are the substances that can vary in the degree of biota accumulation. And at some time it can become a source of secondary pollution of the surface water.

$C P I$ of the surface waters of the Kherson region was calculated. The results of the calculation are shown in Fig. 2. The analysis of the given figure shows that the maximum value of $C P I$ for the both water uses was noted in 2008. This is explained by the fact that this year a number of the analyzed indicators was maximum (17), which had an impact on the results of CPI calculation. The value of the index for fishery requirements is much higher than for household economic-drinking. In 2014-2015, there is a minimum of CPI, which are caused by several factors:

- reducing a number of analyzed indicators to 10-11;

- a lack of available data in the analysis of the indicators that significantly deteriorated a surface water quality of the region ( $\mathrm{Cr}(\mathrm{VI}), \mathrm{Cu}, \mathrm{Ni}$ etc.). 
In 2016-2018 the list of the indicators was almost indistinguishable from the list in 2005 - 2012. However there is a significant decrease in the value of $C P I$. Such water quality indicators as nitrites, $\mathrm{Cr}$ (VI), $\mathrm{Cu}$ and $\mathrm{Ni}$ have been noted as a mineral resource (according to fishery requirements) in various years.

Based on the obtained data the classification of a surface water quality was made (Table 1 ). As can be seen a surface water quality of the region according to the fishery requirements in the most cases is characterized by classes IVa - IVd, category "very dirty", by household economic-drinking - class II, category "polluted", class IIIa, category "dirty".
The dynamics of water intake, water consumption, and circulating water discharge in the Kherson region was analyzed over a multi-year period (Figures 3-5).

The analysis of the volumes of water intake in the region (Fig. 3) shows that during the study period, there is a constant increase in the indicators with a visible maximum in 2018 (an increase of 1.7 times compared to 2017). The largest water intake is from the surface water sources and the smallest - from the marine ones. Besides, according to the available data, until 2007, no seawater was taken. Groundwater intake has decreased by $25 \%$ over the study period.

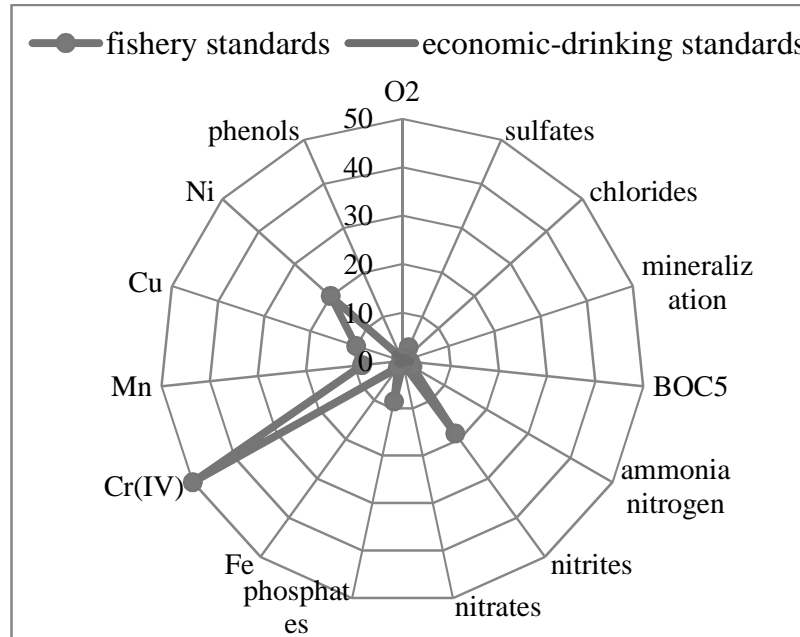

2005

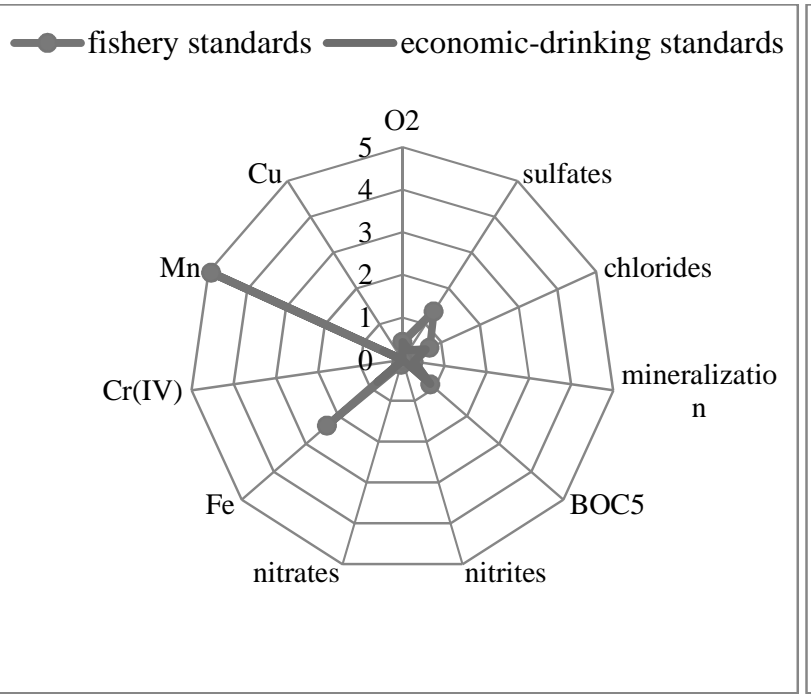

2014

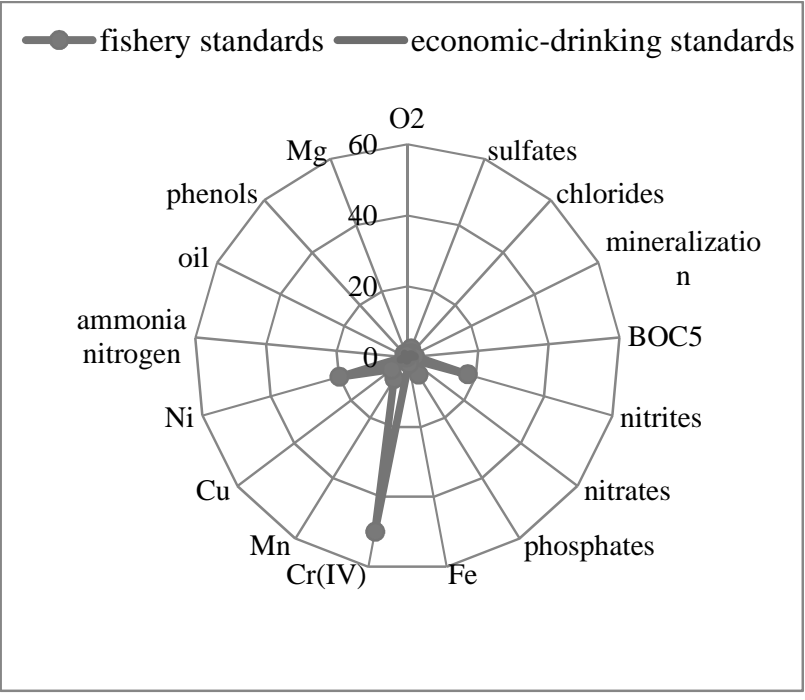

2009

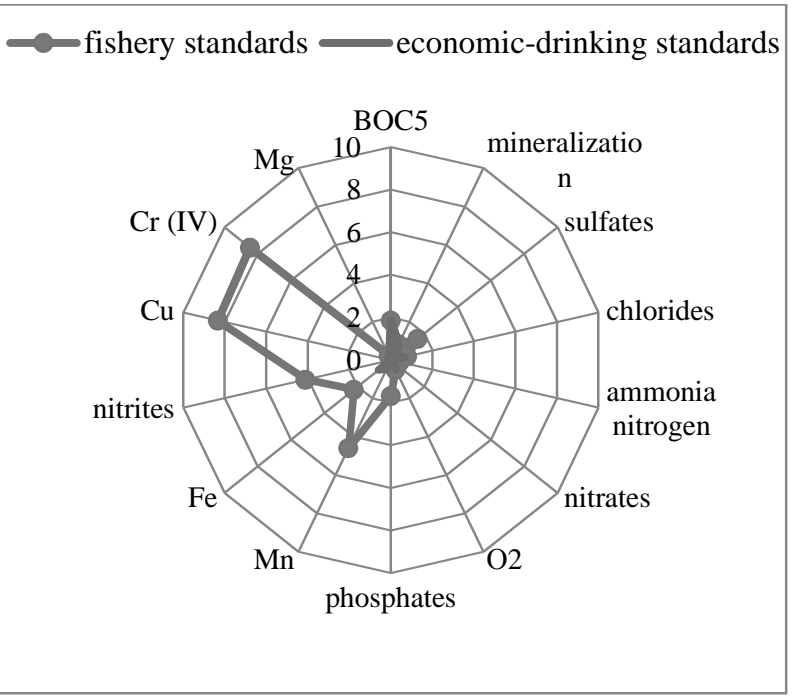

2018

Fig. 1. The quality of the surface water in the Kherson region [5-8] 


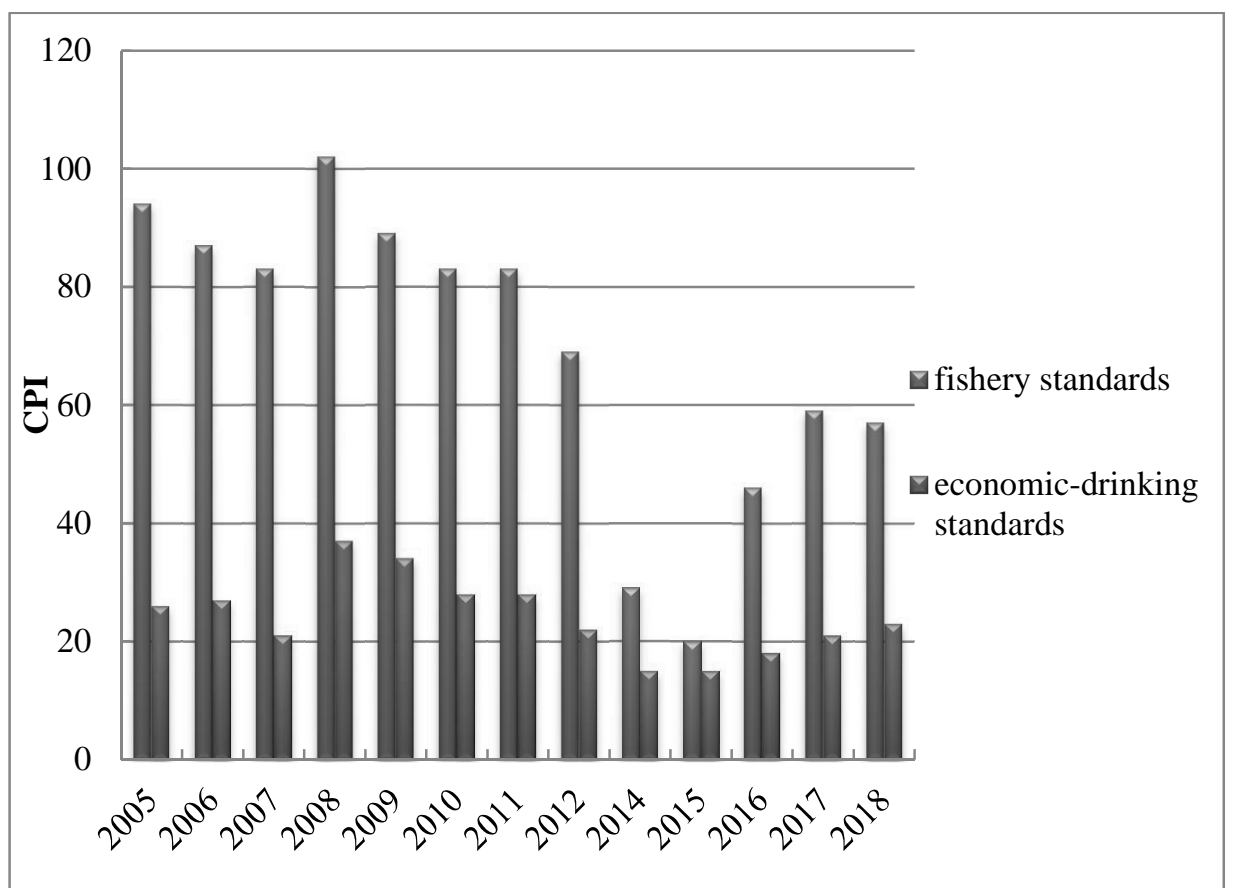

Fig. 2. Dynamics of the CPI change of the surface water in the Kherson region in 2005-2018

Classification of a surface water quality in the Kherson region

\begin{tabular}{|c|c|c|}
\hline Year & Fishery standards & Economic-drinking standards \\
\hline 2005 & IV, very dirty & II, polluted \\
\hline 2006 & IVB, very dirty & IIIa, dirty \\
\hline 2007 & IV , very dirty & II, polluted \\
\hline 2008 & IVB, very dirty & IIIa, dirty \\
\hline 2009 & IV6, very dirty & II, polluted \\
\hline 2010 & IVB, very dirty & IIIa, dirty \\
\hline 2011 & IVB, very dirty & IIIa, dirty \\
\hline 2012 & IVa, very dirty & II, polluted \\
\hline 2014 & IIIa, dirty & II, polluted \\
\hline 2015 & IIIa, dirty & II, polluted \\
\hline 2016 & IVa, very dirty & II, polluted \\
\hline 2017 & IVa, very dirty & II, polluted \\
\hline 2018 & IVa, very dirty & II, polluted \\
\hline
\end{tabular}

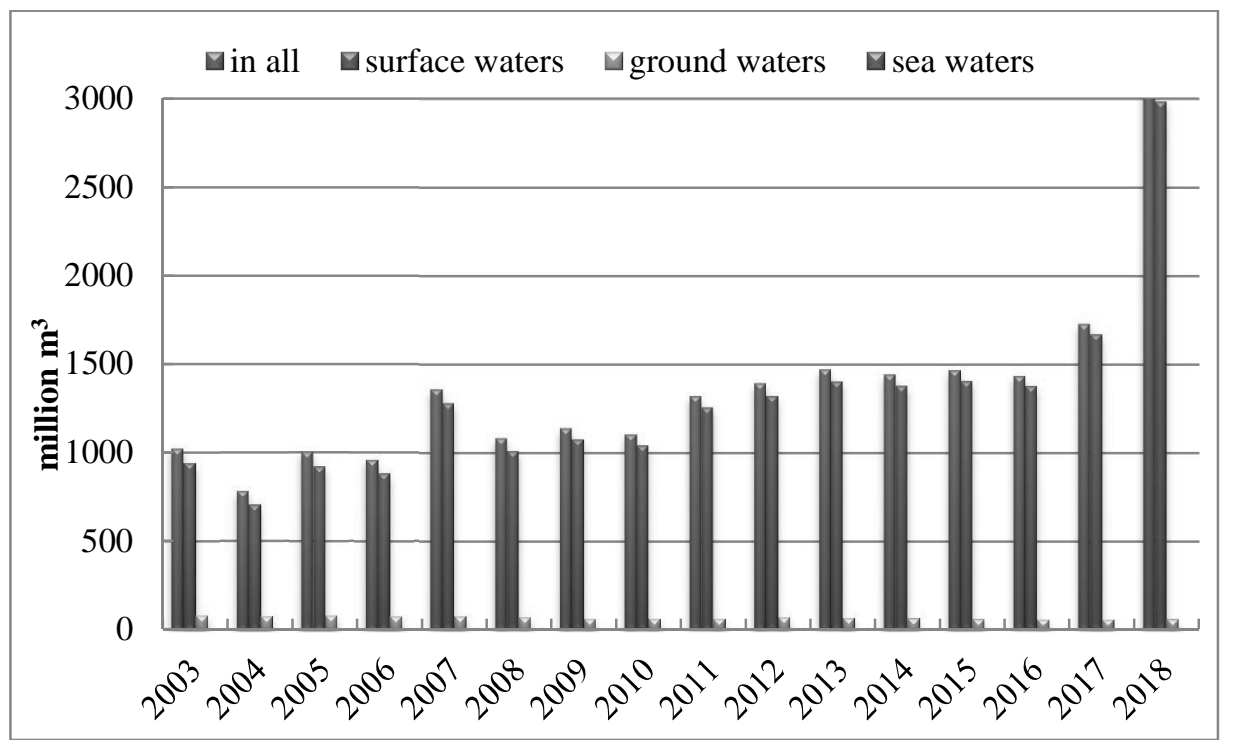

Fig. 3. Dynamics of water intake in the Kherson region in 2003-2018 [5, 6, 8-11] 
With increasing water intake, there is a corresponding increase in water use (Fig. 4). The maximum volumes are noted for irrigation purposes (from 80 to $94 \%$ in recent years), the minimum ones - for other agricultural needs. During the study period, the water use indicators have almost doubled..

With the general increase in water intake, there is a decrease in wastewater discharge (Fig. 5). In 2005-
2006, the volume of the discharges decreased almost twice, and this tendency is ongoing. The maximum number of wastewater emissions is carried out into the surface water bodies. In the total volume of the degree of purification, normative clean wastewater constantly (without purification) dominated. In some years, the share was about $30 \%$.

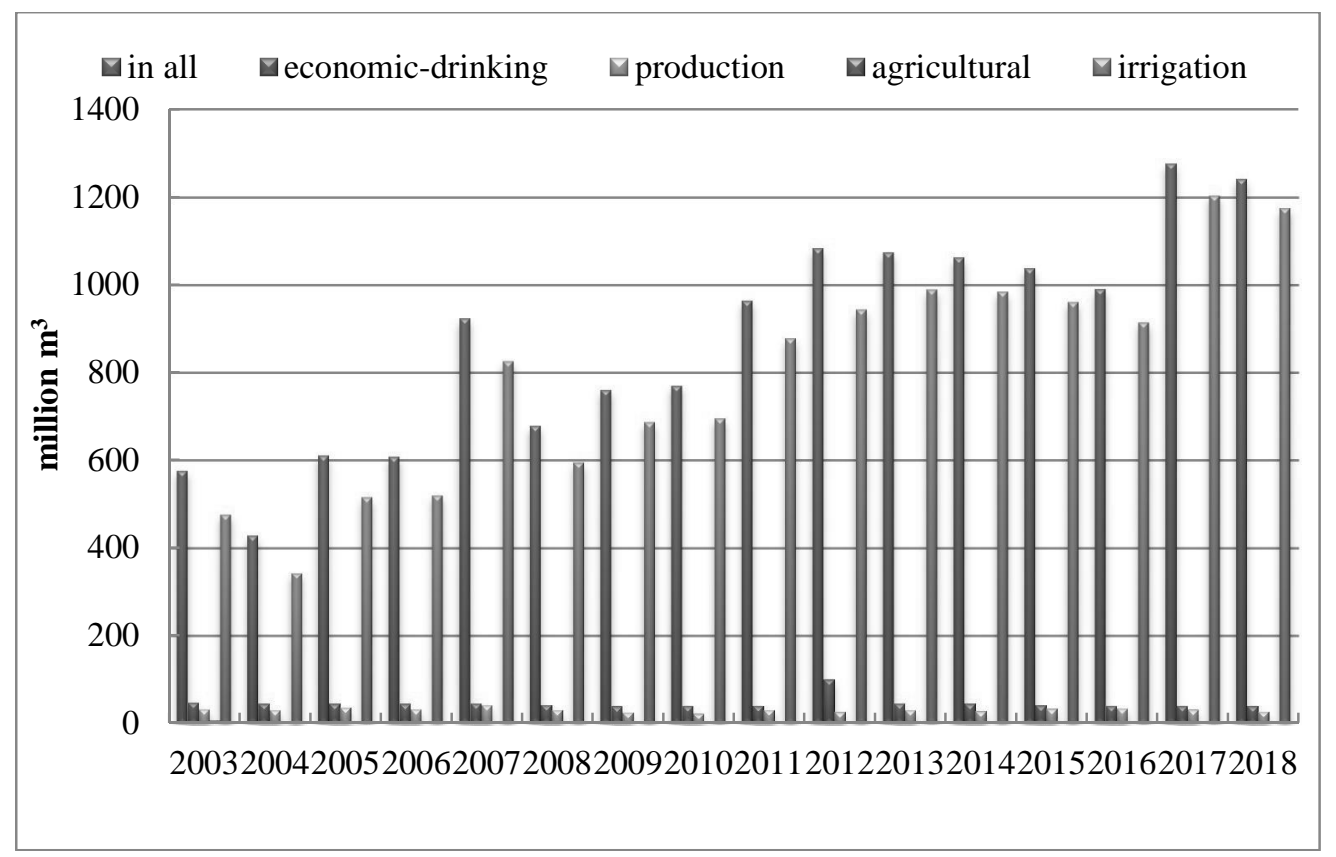

Fig. 4. Dynamics of water use in the Kherson region in 2003 - 2018 [5, 6, 8-11]

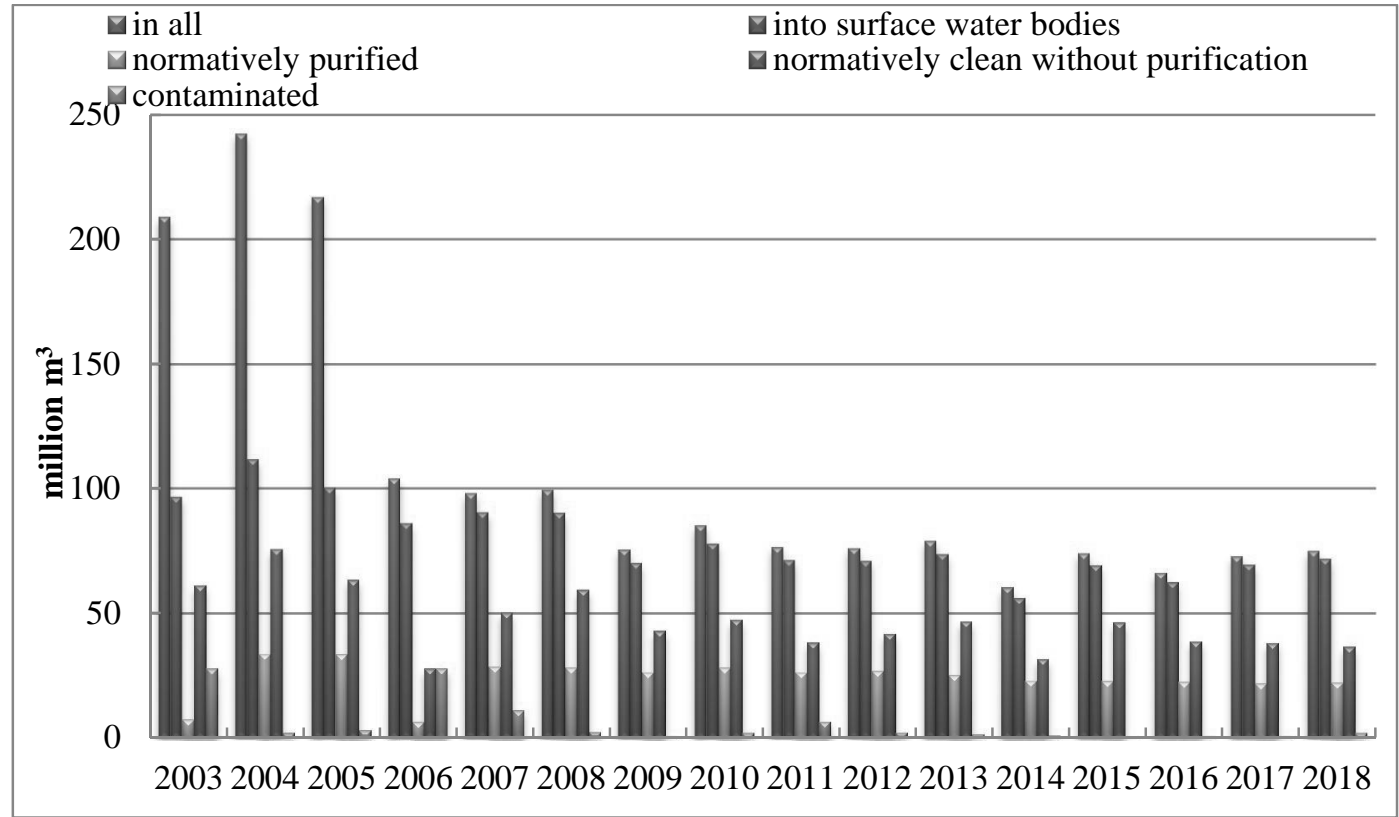

Fig. 5. Dynamics of wastewater discharge in the Kherson region in $2003-2018$ [5, 6, 8-11]

Agricultural enterprises, if compared to other industries, have the largest demand for water in the region.
To estimate the technogenic load on the surface water bodies, the MWO indicator was calculated, based on the values of wastewater discharges as 
well as the pollutants in their composition (Fig. 6). The analysis of the above figure shows that the level of the technogenic load on the surface water bodies for both indicators has significantly decreased

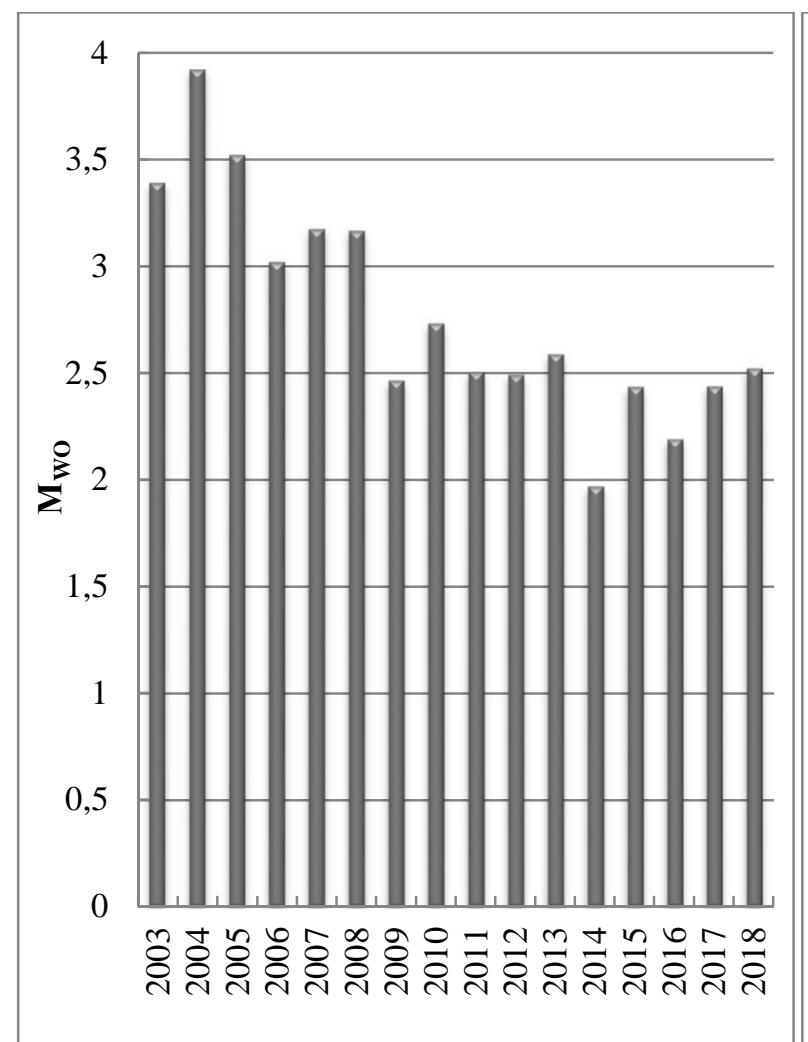

by the volumes of wastewater discharges over the study period. According to both characteristics, the MWO value decreased by almost $30 \%$, as well as the volume of the pollutant discharges in the region.

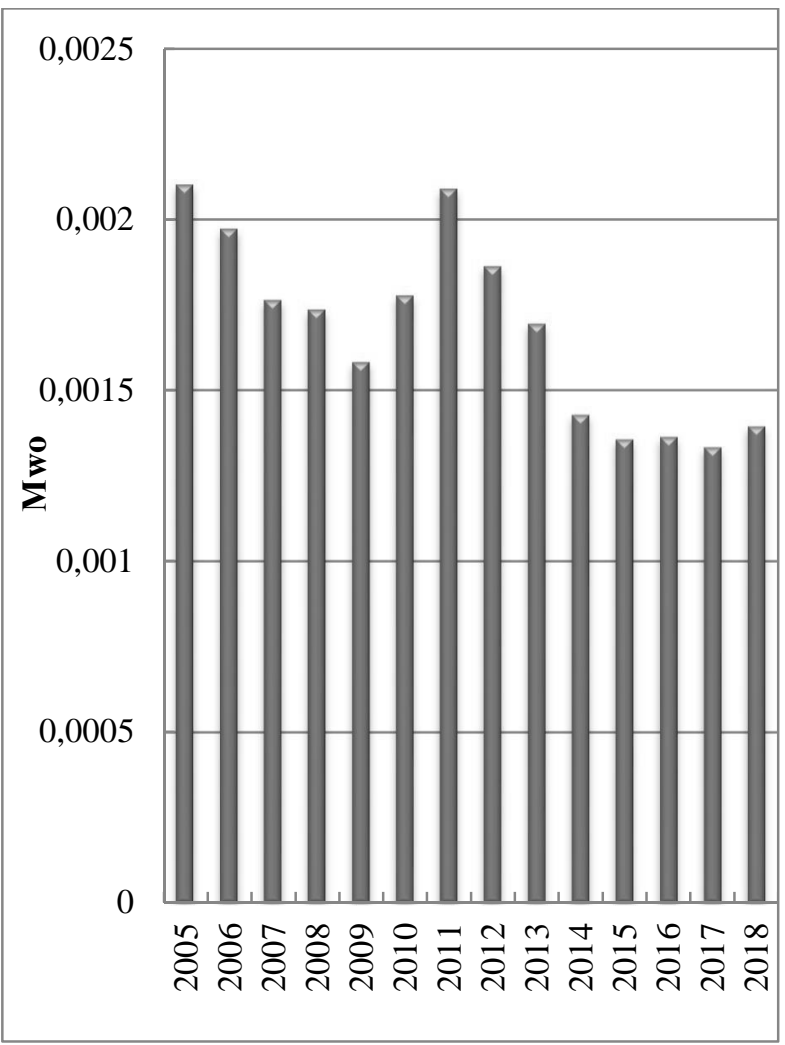

by the volumes of pollutants discharges

Fig. 6. The value of the MWO indicator in the Kherson region in 2003-2018

\section{Conclusions}

As a result of the conducted research, we can make the following conclusions:

- the surface water quality in the region, according to the fishery requirements, in most cases, is characterized by classes IVa - IVd, the category "very dirty", and for drinking water - class II, the category "polluted", and class IIIa, the category "dirty";

- with a general increase in water intake, there is a decrease in the pollutant discharge;

- the level of the technogenic load on the surface water bodies has significantly decreased.

The obtained results are part of the comprehensive study presented in the works of the author with co-authors $[4,12]$, which are devoted to the complex assessment of the technogenic load on the surface water bodies of the Northwest Black Sea regions.

\section{References}

[1] Rehionalna dopovid pro stan navkolyshnoho pryrodnoho seredovyshcha u Khersonskii oblasti u 2017 rotsi. Kherson, 2018. (in Ukrainian)
[2] Igoshin N. I.: Problemy vosstanovleniya maly`x rek i vodoyomov. Gidroekolog. aspekty: Uchebnoe posobie. Burun Kniga, Xar'kov 2009. (in Russian)

[3] Snizhko S. I.: Otsinka ta prohnozuvannia yakosti pryrodnykh vod. Nika-Tsentr, Kyiv 2001. (in Ukrainian)

[4] Chugai A., Dzhura O.: Envir. Probl., 2019, 4 (4), 167. https://doi.org/10.23939/ep2019.04.167

[5] Ekoloh. pasport Kherson. obl. za 2005 r. Kherson, 2006. (in Ukrainian)

[6] Ekoloh. pasport Kherson. obl. za 2009 r. Kherson, 2010. (in Ukrainian)

[7] Ekoloh. pasport Kherson. obl. za 2014 r. Kherson, 2015. (in Ukrainian)

[8] Ekoloh. pasport Kherson. obl. za 2018 r. Kherson, 2019. (in Ukrainian)

[9] Ekoloh. pasport Kherson. obl. za 2007 r. Kherson, 2008 (in Ukrainian)

[10] Ekolohich. pasport Kherson. obl. za 2012 r. Kherson, 2013 (in Ukrainian)

[11] Ekoloh. pasport Kherson. obl. za 2015 r. Kherson, 2016 (in Ukrainian)

[12] Chugai A.V., Dzhura O.S.: Ekoloh. bezpeka, 2018, 2 (26), 59. (in Ukrainian) 